\title{
固体高分子膜水電解槽の性能解析*
}

\author{
小阪 健一郎*1, 谷 俊 宏*2, 吉田 駿*3
}

\section{Thermal Analysis of Solid Polymer Water Electrolysis System}

\author{
Kenichirou KOSAKA*4, Toshihiro TANI and Suguru YOSHIDA \\ ${ }^{* 4}$ Mitsubishi Heavy Ind., Nagasaki R\&D Center, 5-717-1. Fukahori-Machi, Nagasaki, Nagasaki 851-0392, Japan
}

\begin{abstract}
A solid polymer water electrolysis system is a technology to make hydrogen from water by electric power. It uses solid polymer electrolyte membrane, which has proton conductivity. This system has characteristic of low operation temperature, can make high purity hydrogen and oxygen, and needs only water and electric power. Electrolysis is electrochemical reaction with heat generation. So thermal design of large size module is very important to make high performance system, because its performance varies with temperature and it has upper limit temperature about $120^{\circ} \mathrm{C}$. A solid polymer water electrolysis module is composed many stacked cells and separators. A performance simulator of solid water electrolysis module was made, considering three-dimensional distribution of temperature and current density. The influences of module size and operate conditions upon module performance were studied.
\end{abstract}

Key Words: Energy Conversion, Energy Storage, Numerical Analysis, Hydrogen Production, Solid Polymer Electrolyte Membrane, Temperature Distribution

\section{1.緒言}

環境問題解決の一つの手段として自然エネルギーの 利用がある。我が国は化石燃料だけでなく自然エネル ギー資源も高価で乏しいため、水力エネルギーなど安 価な自然エネルギーを海外にて化学エネルギーに変換、 国内に輸送後利用することが検討されている(1)。

自然エネルギーを化学エネルギーに変換する方法と して、水の電気分解による水素製造がある。中でも、 水素イオン導電性を持つ固体高分子膜を利用した固体 高分子膜水分解 (Solid Polymer Water Electrolysis) は、（1）電解液が不要、（2）低温作動、（3）製品水素の 純度が高い等の特徵を持ち、積極的な開発が進められ ている。

水電解の逆反応である燃料電池は、材料特性や電極 性能が温度依存性を持つことから、モジュール構成に おいては、温度分布とセル電圧の予測が重要で、伝熱 と電池性能の連成解析が行われている(2)(3)(4)。固体 高分子水電解装置もその性能は強い温度依存性を持ち、

* 原稿受付 1999 年 5 月 24 日.

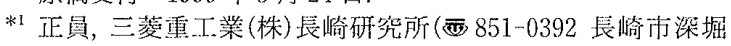
町 5-717-1).

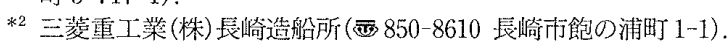

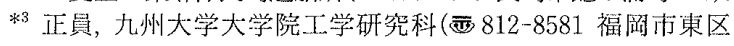
箱崎 $6-10 \cdots 1$ ).

E-mail : kosaka@ngsrdc.mhi.co.jp
性能予測には、電解槽内部の温度分布の解析が必要で ある。更に、電解膜は高分子材料であるので、耐熱限 界以下に電解槽を温度管理することが重要である。

電解槽内の温度分布は水流量や電解電流といった運 転条件や電解槽の大きさなどの影響を強く受ける。し かしながら、これらの影響を考慮して電解槽の性能解 析を試みた研究はこれまで行われていない。そこで、 本研究では、大型電解槽内部の温度場と電解性能の連 成解析が可能なシミュレータを開発し、運転状態と電 解槽構造が性能に与える影響の評価を行った。

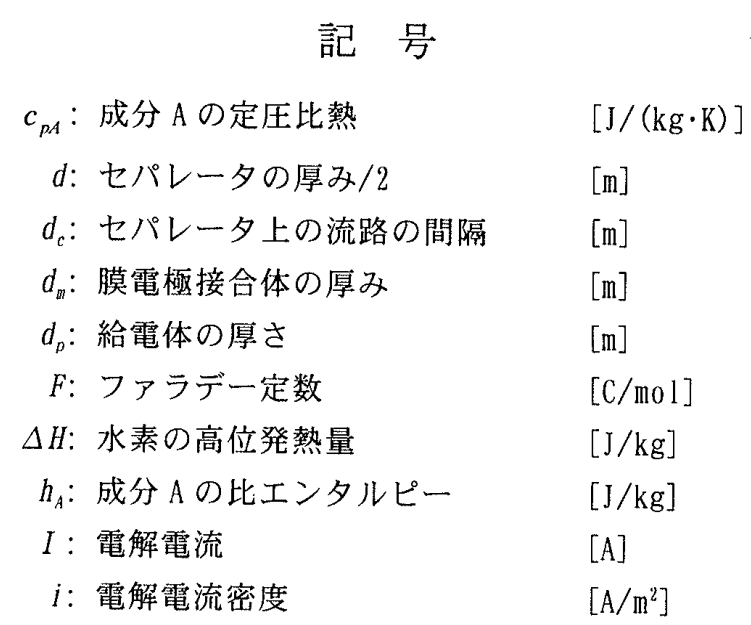


$i_{a v}$ : 平均電流密度

$\left[\mathrm{A} / \mathrm{m}^{2}\right]$

$L$ : 電解槽の長さ

[m]

$M_{A}$ : 成分 $\mathrm{A}$ の分子量

$[\mathrm{kg} / \mathrm{mol}]$

$n$ : 電解槽の積層枚数

$[-]$

$p$ : 電解槽の積層ピッチ

[m]

$p_{c}$ : セパレータ上の流路の間隔

[m]

$Q_{E}$ : 投入電力

[W]

$Q_{F, x}$ : 流体移動による移動熱流量

$[W]$

$Q_{H 2}$ ：単位時間あたりの製造水素が持つ 高位発熱量

$Q_{\lambda, j}: j(x, y, z)$ 万向の熱伝導による

移動熱流量

$T$ : 温度

$T_{R}$ ：電解槽周囲の雾囲気温度

$V$ : 電解電圧

$W$ : 電解槽の幅

[V]

$W_{A}$ : yz 面内の成分 $\mathrm{A} の$ 質量流束

[m]

$W_{c}$ : セパレータ上の流路の間隔

$\left[\mathrm{kg} /\left(\mathrm{s} \cdot \mathrm{m}^{2}\right)\right]$

$\alpha$ : 電解槽外面の熱伝達率

[m]

$\eta_{E}:$ エネルギー効率

$\left[\mathrm{W} /\left(\mathrm{m}^{2} \cdot \mathrm{K}\right)\right]$

$[-]$

$\eta_{i}$ : 電流効率

$[-]$

$\eta_{\text {叫: 水利用率 }}$

$[-]$

$\lambda_{A}$ : 構成要素 A の熱伝導率

$[\mathrm{W} /(\mathrm{m} \cdot \mathrm{K})]$

$\lambda_{j}$ : 電解槽 $\mathrm{j}(\mathrm{x}, \mathrm{y}, \mathrm{z})$ 方向の

等価熱伝導率

$[\mathrm{W} /(\mathrm{m} \cdot \mathrm{K})]$

\section{2. 固体高分子水電解装置}

固体高分子水電解は、水素イオンを透過する固体高 分子電解質膜を利用した水電解法の一つである。この 反応式は次式で表される。

$$
\begin{aligned}
& \text { Anode }: \mathrm{H}_{2} \mathrm{O} \rightarrow \frac{1}{2} \mathrm{O}_{2}+2 \mathrm{H}^{+}+2 e^{-} \cdots \cdots \cdot(1) \\
& \text { Cathode : } 2 \mathrm{H}^{+}+2 e^{-} \rightarrow \mathrm{H}_{2} \cdots \cdots \cdots \cdots \text { (2) } \\
& \text { Total : } \mathrm{H}_{2} \mathrm{O} \rightarrow \mathrm{H}_{2}+\frac{1}{2} \mathrm{O}_{2} \cdots \cdots \cdots \cdots \text { (3) }
\end{aligned}
$$

固体高分子水電解装置の基本構成を図 1 に示す。固 体高分子膜の両面に陰極と陽極を取り付けたものを膜 電極接合体と呼んでいる。電流およびガスと水の導通 確保のために、導電性多孔質製の給電体を介して膜電 極接合体をセパレータと呼ぶ金属板で挟んでいる。陽 極側では、水が分解されて酸素ガスが発生し、酸素・ 水の二相流として排出される。陰極側では、高分子膜 を通過してきた水素イオンが電子と結合して水素ガス となり、水和水とともに水素・水の二相流として排出 される。
電解槽は、図 2 に示すように、図 1 の基本要素を電 気的に直列積層することによって構成される。実際に は、水の供給ヘッダおよび酸素側と水素側にそれぞれ の排出ヘッダを設置する必要があるが、本図では省略 している。積層された電解槽に電解電力を供給するた めに、電解槽は金属製のブスバで挟まれている。電解 槽の大きさは、例えば水素製造容量を $1000 \mathrm{~m}^{3} / \mathrm{h}$ 亡仮 定すると、電流密度が $3 \mathrm{~A} / \mathrm{cm}^{2}$ で運転した場合で $1 \mathrm{~m}^{2} \times$ 100 段となる。

なお、膜電極接合体として用いるフッ素系高分子材 料製イオン交換膜には、作動温度に上限があるため、 電解時に発生する熱を除去する必要がある。電解槽へ 供給する水は、水素の原料としてだけでなく、膜電極 接合体の泠却の機能を併せて持つことになる。

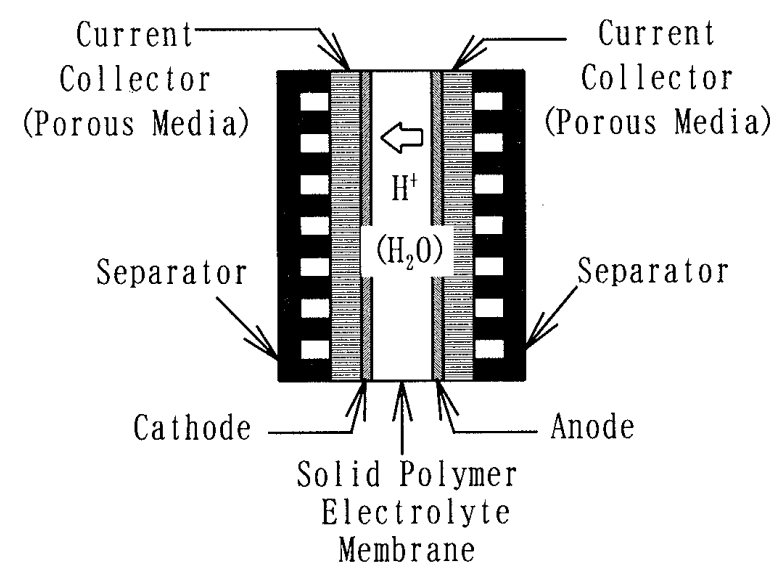

Fig.1 Concept of solid polymer water electrolysis

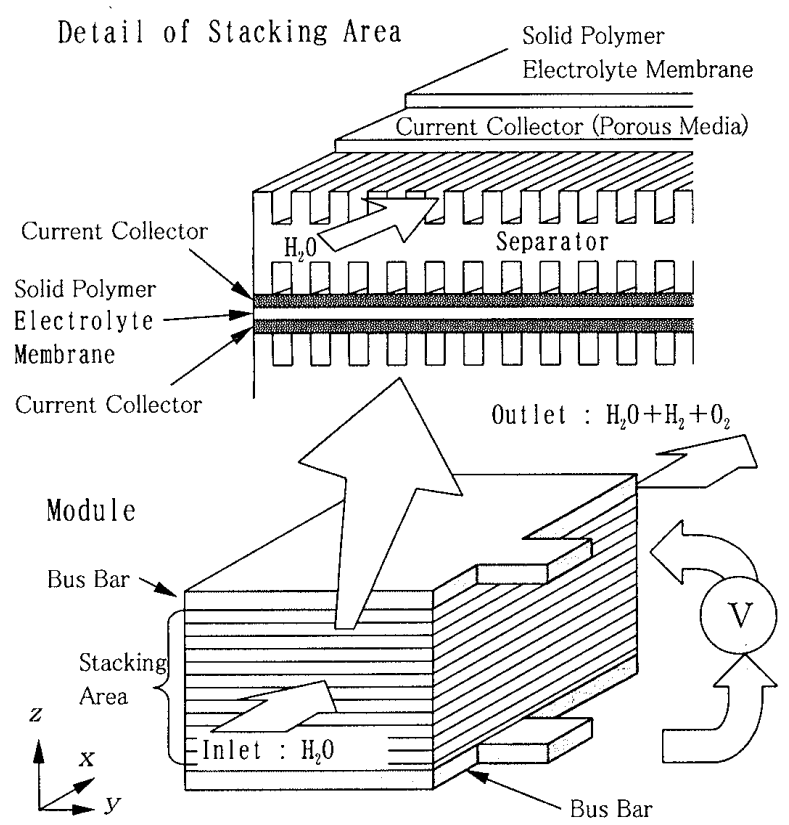

Fig.2 Structure of module 


\section{3.解析手法}

前節で述べたような固体高分子膜水電解槽の温度分 布と電解性能の連成解析を行うためのシミュレータを 作成する。

$3 \cdot 1$ 解析モデル $x, y, z$ の座標系を図 2 に示 すようにとる。電解槽は積層方向にセパレータで仕切 られているため、 $Z$ 方向での流体の移動汢無い。セパ レー夕は多数の溝状の流路を持ち、流路方向である $\mathrm{x}$ 方向には流体が移動するが、y 方向への流体移動は給 電体と膜電極接合体の内部の夕であり無視する。電解 槽内の熱移動は、積層構造内部の熱伝導と、電解槽内 部を移動する水と水素および酸素の熱輸送による。

前節で示したように、水素製造量が $1000 \mathrm{~m}^{3} \mathrm{r} / \mathrm{h}$ の電 解槽は $1 \mathrm{~m}^{2} \times 100$ 段であるので、積層ピッチを $10 \mathrm{~mm}$ と 仮定すると、その大きさは約 $1 \times 1 \times 1 \mathrm{~m}$ である。図 2 に示すように電解槽全体は異材が積層された構造を持 つが、電解槽全体の大きさに対して、図 1 に示した積 層構成要素の厚みは小さいので、セパレータと膜およ び流体を合わせて、電解槽を均質異方性の連続体と見 なすことにする。なお、水と水素あるいは酸素の二相 流体と固体壁間の温度差は $1{ }^{\circ} \mathrm{C}$ 程度以下と十分に小さ いことを計算で確認している。

電解槽の外面は熱伝達境界、断熱境界または温度境 界から境界条件を選択して適用することができるが、 本論文の計算は、すべて熱伝達境界とした。また、電 解槽の上下端に設けている電流導入部のブスバでは、 これを介して周用への放熱があるので、この部分の厚 みと熱伝導率を与えて熱伝導計算を行った。

$3 \cdot 2$ 保存式 上述のモデルに基づいて、物質 およびエネルギーの保存式を考える。均質異方性の連 続体と見なした電解槽の微小体積要素 $\Delta x \Delta y \Delta z$ に関す るエネルギーと物質の収支の概念を図 3 に示す。

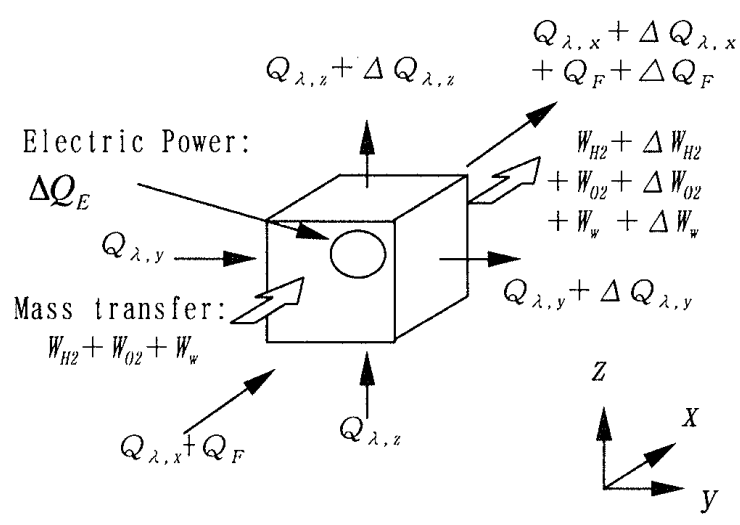

Fig. 3 Heat and mass balances of an elemental volume
流体移動によって微小体積要素に出入りする熱量の 正味として単位時間に要素から出てゆく熱量 $\Delta Q_{F}$ は、

$$
\Delta Q_{F}=\left[\begin{array}{l}
\Delta h_{H_{2}} \cdot W_{H_{2}}+\Delta h_{O_{2}} \cdot W_{O_{2}}+\Delta h_{W} \cdot W_{W} \\
+h_{H_{2}} \cdot \Delta W_{H_{2}}+h_{O_{2}} \cdot \Delta W_{O_{2}}+h_{W} \cdot \Delta W_{W}
\end{array}\right] \cdot \Delta y \Delta z
$$

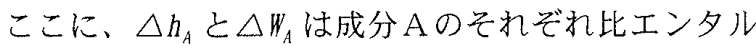
ピーと質量流束の区間 $\triangle x$ における変化量である。

熱伝導によって微小体積要素に出入りする熱量の正 味として単位時間に要素から出てゆく熱量 $\triangle Q_{\text {：は、 }}$

$$
\begin{aligned}
\Delta Q_{\lambda} & =\Delta Q_{\lambda x}+\Delta Q_{\lambda y}+\Delta Q_{\lambda z} \\
& =-\left(\lambda_{x} \frac{\partial^{2} T}{\partial x^{2}}+\lambda_{y} \frac{\partial^{2} T}{\partial y^{2}}+\lambda_{z} \frac{\partial^{2} T}{\partial z^{2}}\right) \cdot \Delta x \Delta y \Delta z \cdots
\end{aligned}
$$

微小体積要素に投入される電力 $\triangle Q_{E}$ は、

$$
\Delta Q_{E}=\frac{1}{p} \cdot i \cdot V \cdot \Delta x \cdot \Delta y \cdot \Delta z
$$

微小体積要素のエネルギー収支は次式で表される。

$$
\Delta Q_{E}=\Delta Q_{F}+\Delta Q_{\lambda}
$$

式 (4) は電解反応に伴う内部エネルギーの変化を含 んでおり、この項は次のとおりに変形できる。

$$
h_{H_{2}} \cdot \Delta W_{H_{2}}+h_{O_{2}} \cdot \Delta W_{O_{2}}+h_{W} \cdot \Delta W_{W}=\Delta H \cdot \Delta W_{H_{2}}
$$

更に、電気分解に関するファラデーの法則より式 (8) は次式に変形できる。

$$
\Delta H \cdot \Delta W_{H_{2}}=\frac{i \cdot \eta_{i}}{2 \cdot F} \cdot M_{H_{2}} \cdot \Delta H \cdot \Delta x \frac{1}{p} \cdots \cdots \cdots \cdots
$$

式 (4)，(5)，(6)，(8)および(9)を式 (7) に代入し、比 エンタルピーを定圧比熱を用いて書き直すと次式を得 る。

$$
\begin{array}{r}
\frac{i}{p} \cdot\left(V-\frac{\eta_{i}}{2 F} \cdot \Delta H \cdot M_{\mathrm{H}_{2}}\right)=\left(C P_{\mathrm{H}_{2}} \cdot W_{\mathrm{H}_{2}}+C P_{\mathrm{O}_{2}} \cdot W_{\mathrm{O}_{2}}+C p_{W} \cdot W_{W}\right) \frac{\partial T}{\partial x} \\
-\left(\lambda_{x} \cdot \frac{\partial T^{2}}{\partial x^{2}}+\lambda_{y} \cdot \frac{\partial T^{2}}{\partial y^{2}}+\lambda_{z} \cdot \frac{\partial T^{2}}{\partial z^{2}}\right) \cdots(10)
\end{array}
$$

電荷の保存に関しては、

$$
I=\iint i \cdot d x \cdot d y
$$

水素、酸素および水の保存の式はそれぞれ次式で表 される。

$$
\begin{aligned}
& \Delta W_{H_{2}}=\frac{i \cdot \eta_{i}}{2 \cdot F \cdot p} \cdot M_{H_{2}} \cdot \Delta x \\
& \Delta W_{O_{2}}=\frac{i \cdot \eta_{i}}{4 \cdot F \cdot p} \cdot M_{O_{2}} \cdot \Delta x \\
& \Delta W_{W}=\frac{i \cdot \eta_{i}}{2 \cdot F \cdot p} \cdot M_{W} \cdot \Delta x
\end{aligned}
$$


$3 \cdot 3$ 電解電圧 高分子材料の膜電極接合体に 比べて金属製のセパレー夕は導電率が十分に高いため に、面内電位分布は無いと仮定して、 $x y$ 面内での電 解電压の拘束条件は次式で表される。

$$
\frac{\partial V}{\partial x}=\frac{\partial V}{\partial y}=0
$$

電解電圧は電流密度、運転温度および圧力の影響を 受ける。電極性能など個々の構成材料から電圧を予測 することも然料電池では検討されている(5)が、ここで は、 $50 \mathrm{~cm}^{2}$ (幅 $71 \mathrm{~mm}$, 長さ $71 \mathrm{~mm}$ )の電極面積を持つ膜電 極接合体 1 枚からなる小型電解槽を用いた性能試験に よって得られた運転温度に対する電解電圧のデータを 用いることにする。本研究で対象とする $1 \mathrm{~m}^{2}$ クラスの 電極面積を持つ電解槽に対して、この電解槽は十分に 小さく、内部を等温と見なすことができる。この性能 試験の結果を図 4 に示す。本計測結果より、電解槽の 電解特性の実験式として次式が得られる。

$$
V=a_{2} \cdot i^{2}+a_{1} \cdot i+a_{0}
$$

ここに、

$$
\begin{aligned}
& a_{2}=4.59 \times 10^{-12} \cdot T-5.48 \times 10^{-10} \cdots \cdots \cdots \cdots \cdots \\
& a_{1}=-2.90 \times 10^{-7} \cdot T+4.78 \times 10^{-5} \cdots \cdots \cdots \cdots \cdots \cdots \cdots \cdots \cdots \cdots \cdots \cdots \cdots \cdots \\
& a_{0}=1.51 \cdots \cdots \cdots \cdots \cdots \cdots
\end{aligned}
$$

これにより、電流密度 $i\left[\mathrm{~A} / \mathrm{m}^{2}\right]$ と運転温度 $T\left[{ }^{\circ} \mathrm{C}\right]$ に依 存した電解電圧 $V[V]$ を得ることができる。図 4 中の 実線は式(16)からの算出值を示しており、計測值をよ く表していることがわかる。

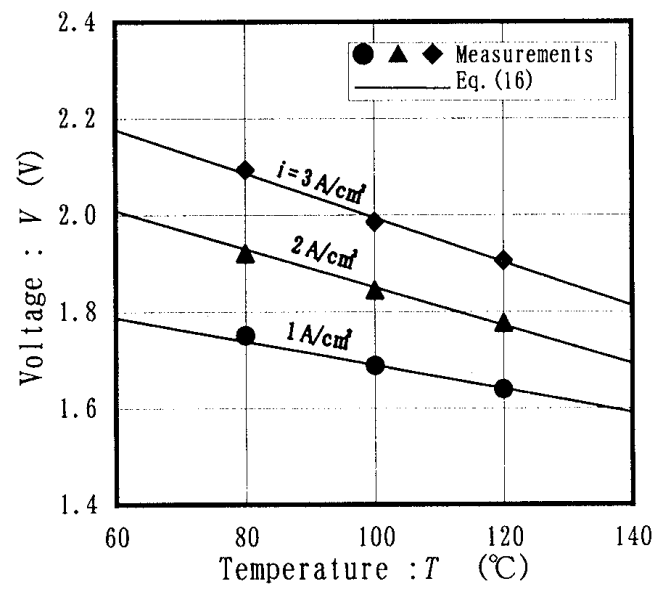

Fig.4 Performance test result of a small module

$3 \cdot 4$ エネルギー効率電解槽のエネルギー 効率は、投入電力に対する製造水素の高位発熱量の比 で定義される。電解槽に投入される電力 $Q_{E}$ は次式で 表される。

$Q_{E}=I \cdot V \cdot n$
一方、製造水素の持つ高位発熱量 $Q_{H 2}$ は次式である。

$$
Q_{H_{2}}=\frac{I \cdot \eta_{i} \cdot \Delta H \cdot M_{H_{2}} \cdot n}{2 F} .
$$

よって、エネルギ一効率 $\eta_{E}$ は次式により与えられる。

$$
\eta_{E}=\frac{\eta_{i} \cdot \Delta H \cdot M_{H_{2}}}{2 F \cdot V}
$$

前項で述べた幅 $71 \mathrm{~mm}$ 、長さ $71 \mathrm{~mm}$ の小型電解槽の性 能試験における電流効率 ク,の計測値はほぼ 1 であり、 本論文では $\eta_{i}=1$ として取り扱った。

$3 \cdot 5$ 電解槽の熱物性值 図 5 に示す電解槽構成 部分の各材料の熱伝導率として以下の值を用いる。

$$
\text { セパレータ(チタン) : } \lambda_{s}=20.0 \mathrm{~W} /(\mathrm{m} \cdot \mathrm{K})
$$

給電板 （チタン瀻維焼結体）： $\lambda_{\mathrm{p}}=10.0 \mathrm{~W} /(\mathrm{m} \cdot \mathrm{K})$

膜電極接合体 (フッ素系高分子) : $\lambda_{\mathbb{\#}}=0.15 \mathrm{~W} /(\mathrm{m} \cdot \mathrm{K})$

電解中は多孔体である給電板中の空げきは水および 電解により発生するガスで充満されている。また、セ パレータの溝部にも水とガスが存在するが、水の熱伝 導率は例えば温度 $80^{\circ} \mathrm{C}$ で約 $0.66 \mathrm{~W} /(\mathrm{m} \cdot \mathrm{K})$ であり、セ パレータや給電板の熱伝導率に比べて十分に小さく、 ガスの熱伝導率は更に小さい。したがって、空げき内 および溝内の流体の熱伝導に対する寄与は十分に小さ く無視できる。このことから、積層方向の等価熱伝導 率入，は、セパレー夕の溝と膜電極接合体および給電 体の積層構造を考虑して、次式で表すことができる。

$$
\lambda_{z}=\frac{d+d_{P}+d_{m} / 2}{\frac{d-d_{C}}{\lambda_{s}}+\frac{d_{C}}{\lambda_{s} \cdot\left(p_{C}-W_{C}\right) / p_{C}}+\frac{d_{P}}{\lambda_{P}}+\frac{d_{m}}{2 \lambda_{m}}} \cdots
$$

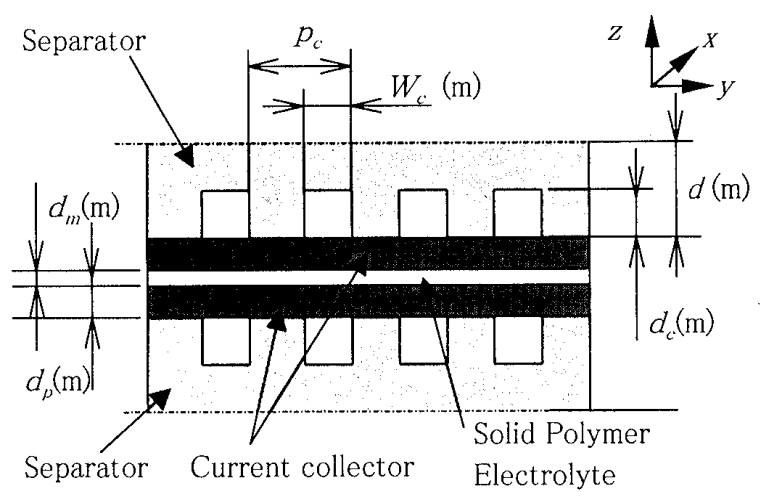

Fig. 5 Detail of stacking area

積層面内方向の熱伝導についてはセパレータの熱伝 導が支配的であると考えられるので、溝方向である $\mathrm{x}$ 方向の等価熱伝導率 $\lambda_{x}$ を近似的に次式で表す。

$$
\lambda_{x}=\lambda_{s} \cdot \frac{d-d_{C}+d_{C} \frac{p_{c}-W_{c}}{p_{c}}}{d+d_{P}+d_{m} / 2}
$$


y 方向の熱伝導については、セパレータ非溝部の熱 伝導が支配的であると考えられるので、等価熱伝導率 $\lambda$, を次式で近似する。

$$
\lambda_{y}=\lambda_{s} \cdot \frac{d-d_{c}}{d+d_{p}+d_{m} / 2}
$$

電解槽内部の各流体の定圧比熱は一定として、下記 の值を用いる。

$$
\begin{aligned}
& \text { 水 }: c_{p W}=4.19 \mathrm{~kJ} /(\mathrm{kg} \cdot \mathrm{K}) \\
& \text { 水素 : } c_{p H_{2}}=14.4 \mathrm{~kJ} /(\mathrm{kg} \cdot \mathrm{K})
\end{aligned}
$$$$
\text { 酸素 : } c_{p o_{2}}=0.94 \mathrm{~kJ} /(\mathrm{kg} \cdot \mathrm{K})
$$

また、水素の高位発熱量 $\triangle H=142.92 \mathrm{MJ} / \mathrm{kg}$ とする。 $3 \cdot 6$ 計算手順本論文で対象とする電解槽は直 方体であり、電解槽に $x, y$ および $z$ 方向の直交座標系 の解析格子を適用し、式(10)を差分式に変換して数値 計算を行った。

温度場と電解性能の連成解析を行うためのアルゴリ ズムを図 6 に示す。電解槽の大きさや運転条件である 電解電流、水の流量と温度、周囲の境界条件などの計 算条件を読み込んだ後、電解槽の温度および電解電圧 を初期值として仮定する。式(11)に示されるように電

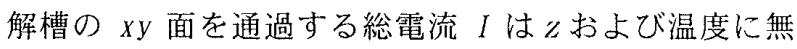
関係に一定であり、 $x y$ 面内の通過電流が所定電流と なるように式 (16)を用いて電圧 $V$ 収束計算を行う。 その具体的な手順を以下に示す。

（1）計算対象とする $x y$ 断面の平均温度 $T_{a v c}$ を求める。

（2）面内の温度分布を考慮して式(16)より電流密度 $i$ を計算し、更に式(11) から面内電解電流 $I_{t e m p}$ を求 める。

（3） $I_{1 \mathrm{argc1}}$ を計算条件として与えられた電解電流として、 $\left|\left(I_{\text {temp }}-I_{t_{\text {arget }}}\right) / I_{t \text { arget }}\right| \leq 0.0001$ を満たす場合は、電流密 度と電圧が収束したと判断する。

（4）収束に満たない場合には、面内の平均電流電圧特 性を $\left(0, a_{0}\right) ，\left(I_{1 \text { cap }}, V_{o l d}\right)$ を通過する直線と仮定して、 目標電流 $I_{\text {target }}$ が得られるであろう電在 $V_{\text {target }}$ を次 式から算出する。ここに、 $a_{0}$ は式(19)の值、V $V_{0 / d}$ は 現時点での電圧の仮の値である。

$$
V_{\text {target }}=a_{0}+\frac{I_{\text {temp }}}{I_{t \text { arget }}} \cdot\left(V_{\text {old }}-a_{0}\right) \cdots \ldots \ldots \ldots \ldots \ldots
$$

面内の電解電圧 $V$ を $V_{\text {targo }}$ に置き換えて、電流密度 の計算 (2)に戻る。

電圧および電流密度分布の収束計算の結果を用いて、 式(12)，(13)，(14)加ら各流体の流量変化量を、式(10) から温度分布をそれぞれ計算する。

各計算点における温度分布計算前後の温度をそれぞ
れ $T_{\text {old } i, j, k}, T_{n e w, i, j, k}$ として、全ての点で $\left|1-T_{n e w, i, j, k}\right| T_{\text {old }, i, j, k} \mid$ s0.0001であれば、温度分布が収束したものとして計 算結果を出力して終了する。未収束の場合には、各点 の温度を $T_{n e w, i, j, k}$ に入れ替えて電圧および電流密度の収 束計算に戻る。

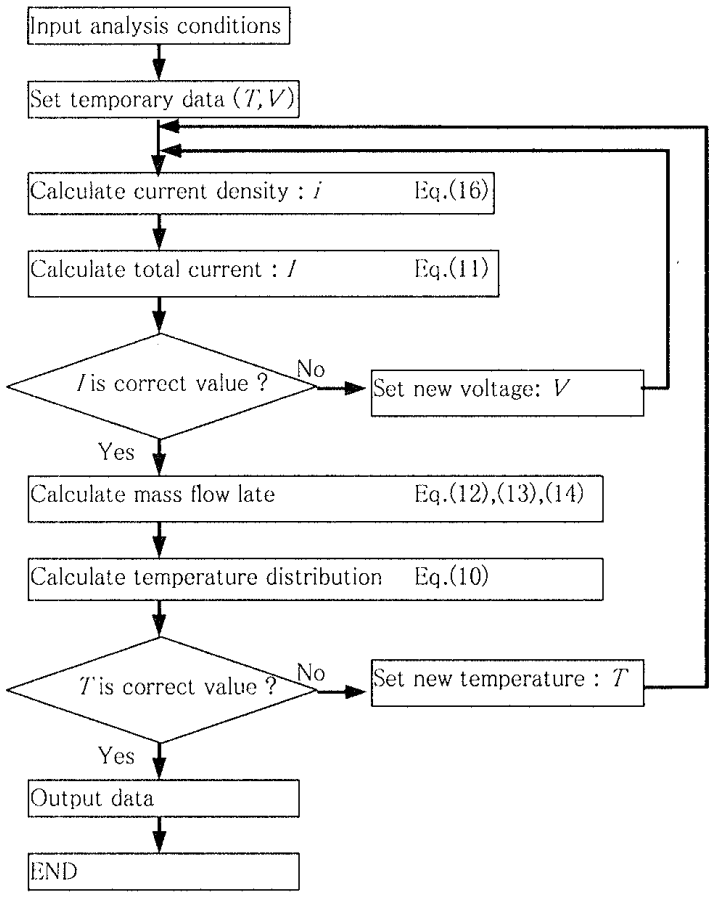

Fig.6 Algorithm of performance analysis

4. 性能計算結果

$4 \cdot 1$ 計算例 本論文においては、電解槽の周 曲の雲囲気温度は $20^{\circ} \mathrm{C}$ と、外周部分の熱伝達率は 自然対流熱伝達と放射伝熱を考慮して $10 \mathrm{w} /\left(\mathrm{m}^{2} \cdot \mathrm{K}\right)$ とし た。前節で述べたシミュレータを用いた性能解析の例 を図 7 および図 8 に示す。純水は電解槽に $80^{\circ} \mathrm{C} て ゙$ 供 給され、電解中の損失による発熱のために、出口では 約 $130^{\circ} \mathrm{C}$ ま加熱されている。外壁から周囲への放熱 のために、電解槽の外面付近は泠却され内部に比べて 温度が低いことがわかる。また、電解槽の温度は出口 端の中心付近で最高になっている。

このような温度分布により電解性能は電解槽内の位 置により変化するが、電解電圧は $x y$ 面内で一定に拘 束されているため、電流密度に不均一が生じている。 すなわち、低温部分では電解膜の抵抗が高くなるので、 電流密度は低く、高温部分では電解膜の抵抗が低下す るため、電流密度は高くなっている。図示した例は電 解槽全体の平均電流密度を $1.0 \mathrm{~A} / \mathrm{cm}^{2}$ としたものである が、最大電流密度は $1.57 \mathrm{~A} / \mathrm{cm}^{2}$ 、最小電流密度は $0.77 \mathrm{~A} / \mathrm{cm}^{2}$ であり、平均電流密度に対して、 $+57 \%,-23 \%$ と大きな電流密度分布を持っている。 


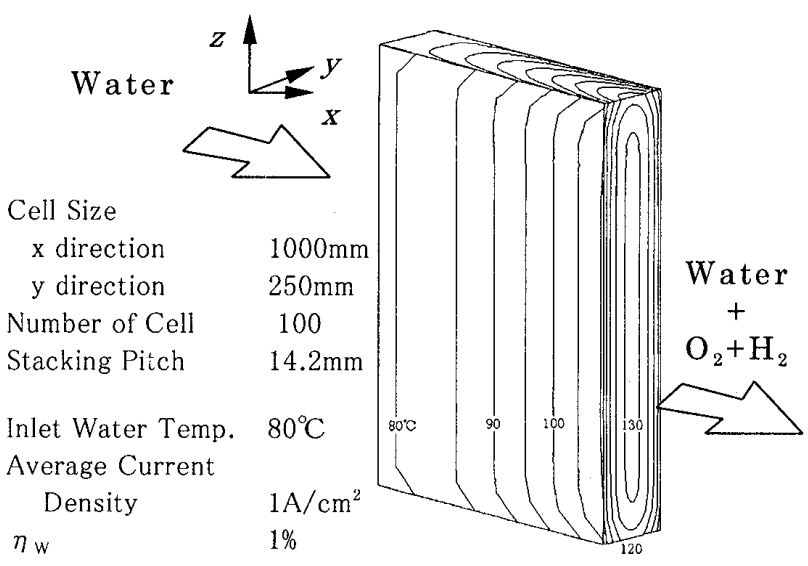

Fig.7 Calculated distribution of temperature

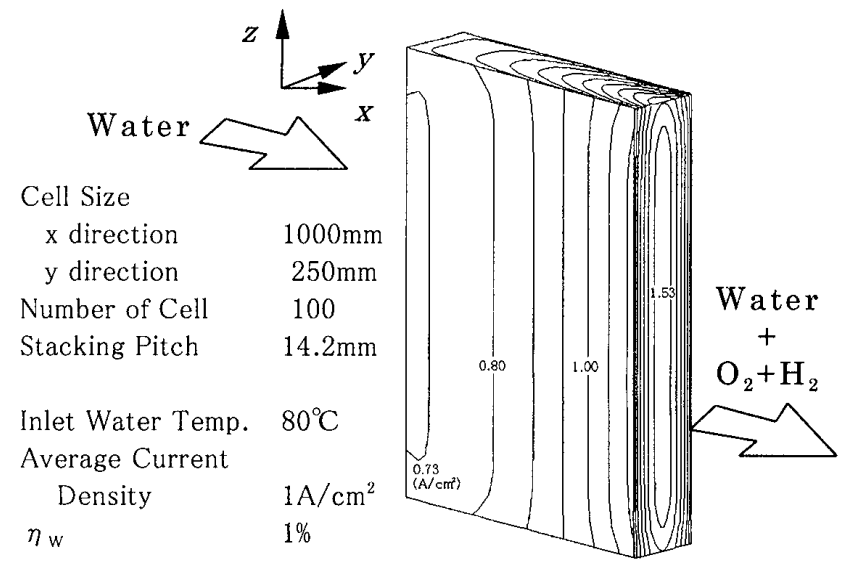

Fig. 8 Calculated distribution of current density

$4 \cdot 2$ セパレータ厚みの影響平均電流密度 $i_{a v}$ と水利用率(供給水量に対する分解された水量の比 率） $n_{W}$ をパラメータとして、幅 $250 \mathrm{~mm}$ 、長さ $1000 \mathrm{~mm}$ のセパレータに対して厚み $2 d$ を変化させた計算を行 った。計算条件を表 1 に示す。

出口端中心付近で生じる電解槽の最高温度 $T_{\max }$ と工 ネルギー効率 $\eta_{E}$ の計算結果を図 9 に示す。セパレー 夕の厚みが増加すると、電解槽の最高温度はいくぶん 低下している。これは側面からの放熱量が増加するた めである。また、電解槽の温度低下により電解電圧が 上昇するために、エネルギー効率もわずかに低下して いる。水利用率 $\eta_{H}$ が $10 \%$ と $5 \%$ の計算結果を比較する と、 $\eta_{\text {H }}$ が低い方が、厚みによる出口温度の変化が小 さい。これは、循環水が輸送する熱量が大きくなり、 相対的にセパレータ内の熱伝導の影響が小さくなるた めと考えられる。平均電流密度 $i_{a v}$ が大の場合、セパレ ータの厚みによる出口温度の変化は極めて小さくなっ ている。これは、電流密度の増加により、エネルギー 効率が低く、電解槽内部の損失、つまり発熱量が増加 し、しかも循環水量が増加することから、セパレータ の熱伝導による放熱の笴与度が低下するためであると 考えられる。
Table 1 Conditions of analys is

\begin{tabular}{|cc||c|c|c|}
\hline $2 d$ & $\mathrm{~mm}$ & 5 & 14 & 30 \\
\hline$p$ & $\mathrm{~mm}$ & 5.2 & 14.2 & 30.2 \\
\hline$n$ & & 100 & 100 & 100 \\
\hline$\lambda_{x}$ & $\mathrm{~W} /(\mathrm{m} \cdot \mathrm{K})$ & 11.00 & 16.80 & 18.50 \\
$\lambda_{y}$ & $\mathrm{~W} /(\mathrm{m} \cdot \mathrm{K})$ & 3.85 & 14.08 & 17.22 \\
\hline$\lambda_{z}$ & $\mathrm{~W} /(\mathrm{m} \cdot \mathrm{K})$ & 3.08 & 6.64 & 10.28 \\
\hline$\alpha$ & $\mathrm{W} /\left(\mathrm{m}^{2} \mathrm{~K}\right)$ & 10 & 10 & 10 \\
\hline$T_{R}$ & ${ }^{\circ} \mathrm{C}$ & 20 & 20 & 20 \\
\hline
\end{tabular}

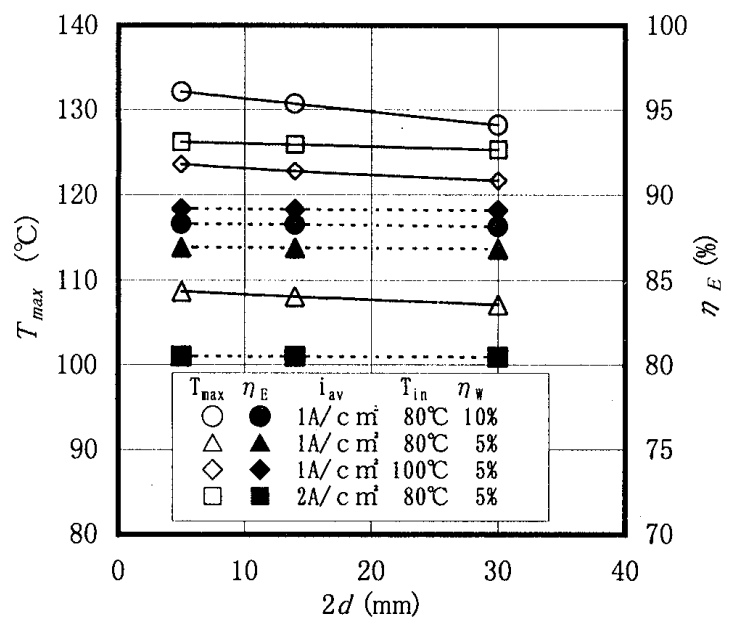

Fig. 9 Influence of separater thickness

$4 \cdot 3$ 運転条件による性能の変化幅 $250 \mathrm{~mm}$ 、 長さ $1000 \mathrm{~mm}$ 、厚さ $14 \mathrm{~mm}$ のセパレータで平均電流密度 が 2 と $3 \mathrm{~A} / \mathrm{cm}^{2}$ の場合について、水利用率をパラメータ として性能計算を行った結果を図 10 に示す。電解槽 内で水温が変化するため、供給水温が $80^{\circ} \mathrm{C}$ 一定と、 電解槽の最高温度 (水の最高局所出口温度) $T_{\max }$ が $120^{\circ} \mathrm{C}$ 一定の二つの場合について計算を行い、入口水温一定 の場合には最高温度 $T_{\max }$ を、最高温度一定の場合には 入口水温 $T_{i l}$ をそれぞれ図示している。更にそれぞれ の場合の電解電圧 $V$ も併示している。計算条件は、表 1 のセパレータ厚さが $14 \mathrm{~mm}$ の場合と同じである。

平均電流密度が $2 \mathrm{~A} / \mathrm{cm}^{2}$ と $3 \mathrm{~A} / \mathrm{cm}^{2}$ のいずれの場合も、 水利用率の増加に伴って供給水温と最高温度の差は大 きくなっている。入口水温固定の場合は、最高温度が 水利用率の増加に伴って上昇する。最高温度を電解膜 の耐熱限界 $120^{\circ} \mathrm{C}$ 以下に抑えるためには、入口水温を 水利用率の增加に伴って下げる必要がある。この傾向 は、電流密度が高い方が顕著であるが、これは発熱密 度が電流密度の上昇に伴って増加するためである。

入口水温固定の場合は、水利用率の増加に伴って、 セルの平均温度が上昇するため、電解電圧が低下する。 平均電流密度は一定であるので、投入電力は電圧に比 
例することから、水利用率の増加にしたがってエネル ギ一効率が向上する。一方、最高温度固定の場合は、 水利用率増加とともに入口温度を下げる必要があるた め、セル平均温度が低下し、電解電圧は上昇する。こ のため、水利用率の増加に伴ってエネルギ一效率が低 下する。
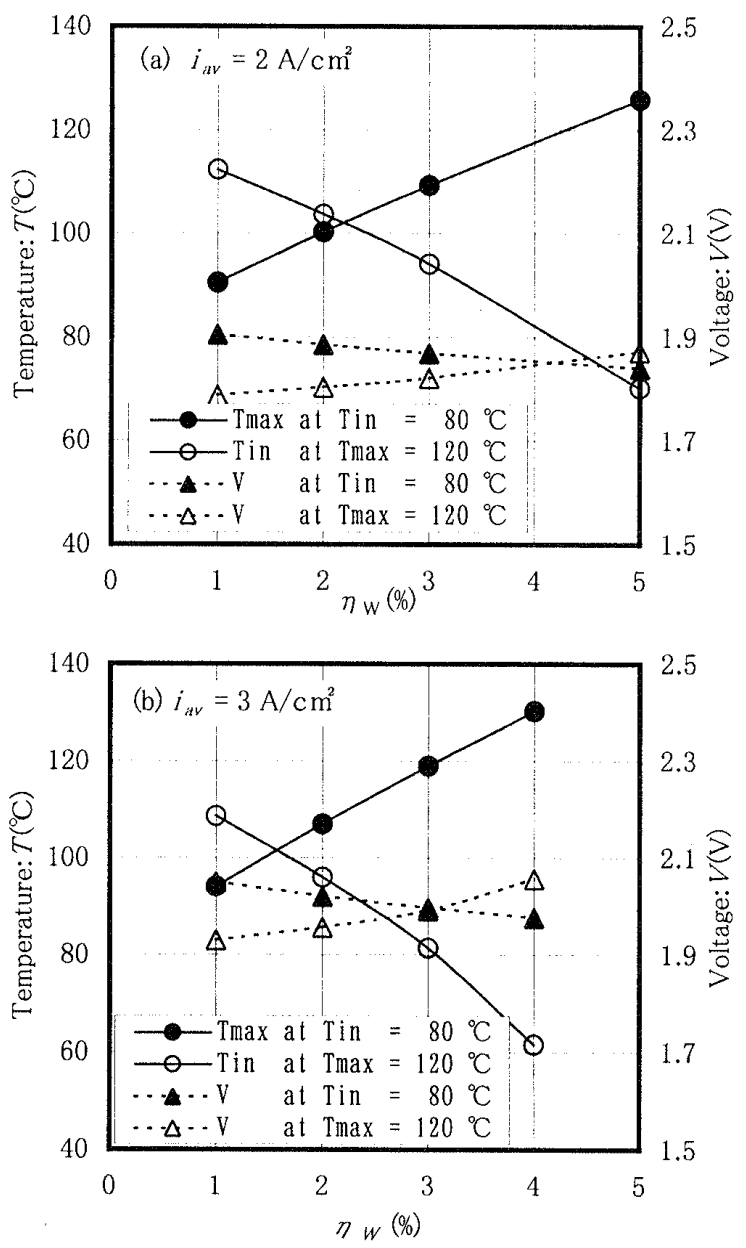

Fig.10 Influence of operation conditions

前に述べたように、膜電極接合体は高分子材料を用 いているため、温度上昇により軟化するため、使用温 度に上限がある。実用上、その值は約 $120^{\circ} \mathrm{C}$ である。 したがって、電解槽の最高温度を $120^{\circ} \mathrm{C}$ 一定とした場 合に最も効率の高い運転が可能である。

図 4 に示した $71 \mathrm{~mm} \times 71 \mathrm{~mm}$ の小型電解糟による性能 試験は、等温場での性能試験と見なすことができる。

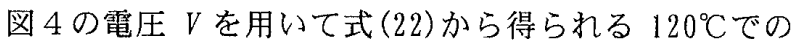
エネルギー効率を等温場でのエネルギ一効率 $\eta_{E 0}$ とす る。最高温度を $120^{\circ} \mathrm{C}$ 一定とした場合の、幅 $250 \mathrm{~mm} 、$ 長さ $1000 \mathrm{~mm}$ の 100 枚積層電解槽でのエネルギー効率 $\eta_{E}$ と $\eta_{E 0}$ の差は、電解槽の大型化に伴う温度分布の 発生によるエネルギー効率の低下を表すことになる。 $\eta_{E 0}-\eta_{E}$ と水利用率 $\eta_{*}$ との関係を図 11 に示す。大
型の電解槽では、温度分布と電流密度分布の影響を受 けてエネルギ一効率が低下することがわかる。水利用 率が低くなると電解槽全体の温度が均一化するため、 小型電解槽とのエネルギ一効率の差異は小さくなる。

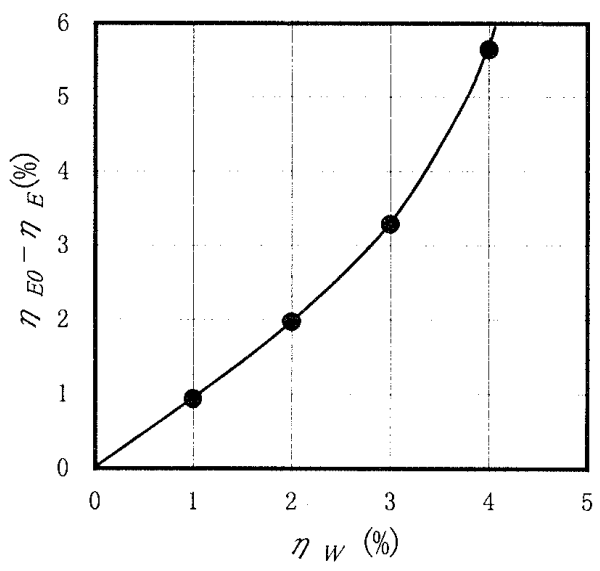

Fig.11 Influence of $\eta_{W}$ on $\eta_{i:}$

$4 \cdot 4$ 電解槽の大きさの影響電解槽の幅お よび長さを変化させて性能計算を行った結果を表 2 に 示す。図 10 と同様に最高温度が $120^{\circ} \mathrm{C}$ 一定になるよ うに供給水の温度を設定した。電解槽の大きさが小さ

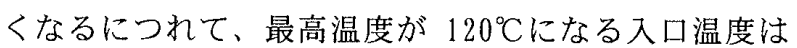
上昇している。図 12 は表 2 中の数値を図示して、工 ネルギー効率と膜電極接合体の面積 (断面積 $L \times M)$ と の関係を示したものである。最高温度 $T_{m a x}$ と入口温度 $T_{i n}$ との差も併示している。膜電極接合体の大面積化 により、温度差 $T_{\max }-T_{i n}$ は増大し、エネルギー効率 $\eta_{E}$ は低下している。そして、 $\eta_{E}$ と $T_{m a x}-T_{i n}$ の変化は、増 減の向きは逆であるが、ほぼ同じ傾向を示している。

Table 2 Influence of module size

\begin{tabular}{|cc||c|c|c|c|c|}
\hline$i_{a v}$ & $\mathrm{~A} / \mathrm{cm}^{2}$ & 1 & 1 & 1 & 1 & 1 \\
$\eta W$ & $\%$ & 10 & 10 & 10 & 10 & 10 \\
$W$ & $\mathrm{~mm}$ & 1000 & 250 & 250 & 100 & 50 \\
$L$ & $\mathrm{~mm}$ & 1000 & 1000 & 250 & 100 & 50 \\
$n$ & & 10 & 10 & 10 & 10 & 10 \\
$T_{i n}$ & ${ }^{\circ} \mathrm{C}$ & 57 & 59 & 67 & 103 & 119 \\
\hline$T_{\max }$ & ${ }^{\circ} \mathrm{C}$ & 120 & 120 & 120 & 120 & 120 \\
$V$ & $\mathrm{~V}$ & 1.725 & 1.723 & 1.704 & 1.659 & 1.643 \\
$\eta_{E}$ & $\%$ & 85.84 & 85.95 & 86.93 & 89.27 & 90.16 \\
\hline
\end{tabular}

図 13 に電解槽内部の温度分布を示す。 $\mathrm{x}$ 方向 (水の 流れ方向)の位置はセル長さ L で規格化している。 $250 \mathrm{~mm} \times 250 \mathrm{~mm}$ の場合には、 $\mathrm{x}$ 万向に温度が大きく上 昇し、出口に近づくにつれて $\mathrm{x}$ 一定の断面上で大きい 温度分布が生じている。小型の電解槽では、x 方向の 温度変化および断面上の温度分布が、大型の電解槽と 
比較して極めて小さい。これは、小型の電解槽の方が 比表面積が大きいために放熱量が増加すること、およ び寸法が小さいためにセパレータの熱伝導によって等 温化されやすいことによると考えられる。

この結果、図 14 に示すように、 $250 \times 250 \mathrm{~mm}$ の電解 槽では、平均電流密度 $\left(1.0 \mathrm{~A} / \mathrm{cm}^{2}\right)$ に対して、0.68A/ $\mathrm{cm}^{2}$ から $1.45 \mathrm{~A} / \mathrm{cm}^{2}$ までの分布を持っているが $50 \times 50 \mathrm{~mm}$ の 電解槽では、各部の電流密度は平均電流密度とほぼ等 しくなっている。

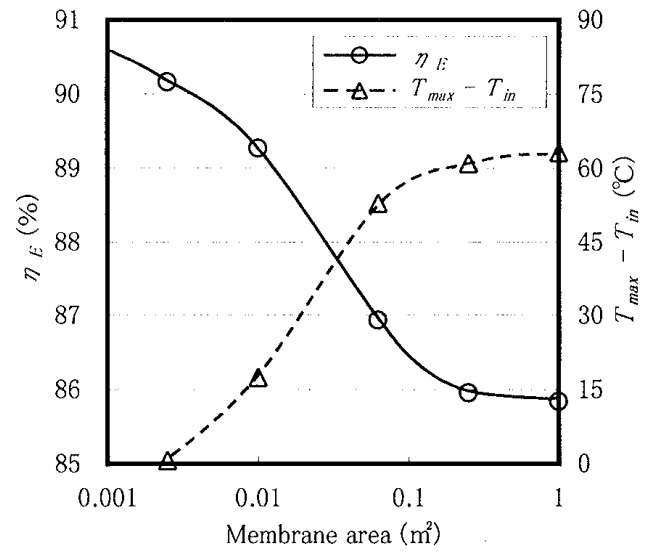

Fig.12 Influence of membrane size on $\eta_{t:}$

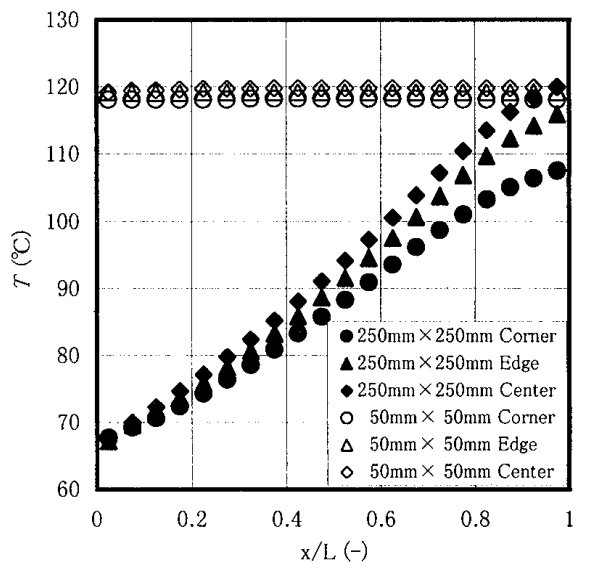

Fig.13 Distributions of temperature

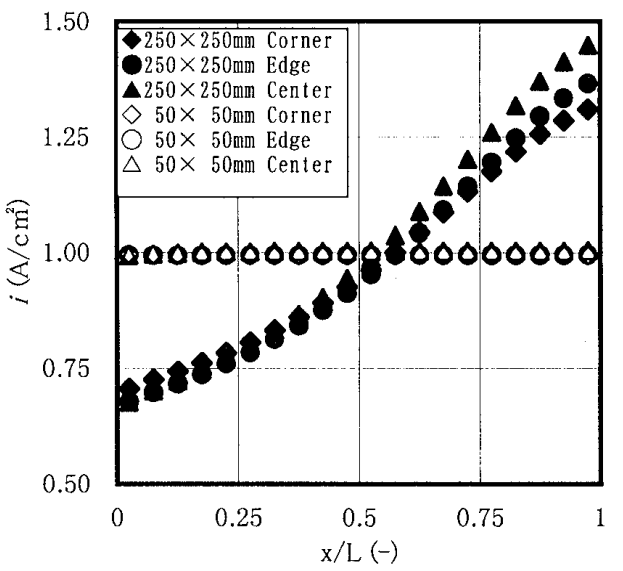

Fig.14 Distributions of current density

\section{5. 結論}

固体高分子水電解槽の三次元性能解析シミュレータ を作成して、各種パラメータを変化させた性能予測計 算を行った。得られた知見は以下のとおりである。

(1) 電解槽では内部発熱により温度分布が生じる。こ の温度分布は、水利用率と電解電流によって異な る。さらに、外面から周囲への放熱の影響を受け るため、電解槽の大きさやセパレー夕の構造によ っても変化し、大型になるほど大きい温度分布に なる。

（2）電解性能の温度依存性から、電解槽内の電流密度 住分布を持つ。

（3）電解膜の耐熱限界によって、電解槽の最高温度が 規定されるために、供給水温と水利用率には上限 が存在する。

（4）電解槽の温度分布とそれに伴う電流密度分布によ り、大型電解槽のエネルギー効率は、小型電解槽 に比べて低下する。

以上の結果から、水素製造量が数 $\mathrm{m}^{3} \mathrm{~N} / \mathrm{h}$ を越える大型 電解槽の開発においては、運転条件の管理が重要であ ることがわかった。特にスタックの性能に対しては水 の循環量が支配的であり、循環水の分配のよしあしが 性能に強い影響を及ぼすことが予想される。また、例 えば、 $250 \times 1000 \mathrm{~mm}$ の電解槽は、水利用率が $1 \%$ 、平 均電解電流が $3 \mathrm{~A} / \mathrm{cm}^{2}$ 以下であれば、入口温度 $80^{\circ} \mathrm{C}$ に 対して出口水温が $94^{\circ} \mathrm{C}$ 以下になるので、常圧運転が 可能と考えられる。

なお、本論文は、新エネルギ産業技術総合開発機構 (NED0)による WE-NET(水素利用国際クリーンエネルギ ーシステム技術)において 1997 年より開始された電解 槽の大型化研究に先立って実施した三菱重工業での研 究をまとめたものである。

\section{文献}

（1） NED0, WE-NET 成果報告書, (1994).

（2）松山ら, 燃料電池シンポジウム予稿集，3, (1996), 114.

（3）脇坂ら,機講論, No.954-2(1995), 223.

（4）土井ら,三井造船技報, No. 148, (1993), 6 .

(5) Weisbrod.K. R, Proton Conduct Fuel Cell,1, (1995), 152. 